\title{
EPIDEMIOLOGY OF GRAPE DOWNY MILDEW IN 2009 AND 2010
}

\author{
János ÁGOSTON ${ }^{1 *}$ \\ ${ }^{1}$ John von Neumann University, Faulty of Horticulture and Rural Development, Department of Agriculture. \\ 6000 Kecskemét, Mészöly Gyula tér 1-3. Hungary \\ https://doi.org/10.47833/2020.1.AGR.003
}

Keywords:
Plasmopara viticola
downy mildew
grape
Hungary
epidemic

Article history:

Received 25 Nov 2019

Revised 15 Dec 2019

Accepted 20 Dec 2019

\begin{abstract}
Plasmopara viticola is one the most important diseases of grapevine in Hungary. It is present in all grape yards, and growers have to spray regularly if they want to have a healthy crop. Downy mildew can cause epidemic depending on the environmental factors of the year. In this paper I compare the disease occurrence in an epidemic and an average year.
\end{abstract}

\section{Introduction}

Grape is the most important fruit bearing crop of Hungary. It's growing area was 17650 ha only in Bács-Kiskun County in 2010 [10], which is 2,098\% of the total area of the county. Being such an important crop its production technology and pest management are well researched and developed.

One of the main pillars of the disease management of grape is the protection against downy mildew (Plasmopara viticola). The pathogen belongs to the Oomycetes phylogenetic group [4-6, 8]. Oospores - it's sexual spore type - form in the second part of the growing season, mainly on the lower leaves. This is the only way the pathogen can overwinter, in leaf litter [8]. Oospores serve as primary inocula in spring, it grows macrosporangia, which forms zoospores inside and releases them under favorable weather conditions $[4,5]$.

For primary infection the average daily temperature must be over $10{ }^{\circ} \mathrm{C}$, and requires a minimum of $10 \mathrm{~mm}$ rainfall within 48 hours $[3,8,11,16]$. Zoospores get on the underside of the leaves by wind or splashing water $[4,5,8]$, this means that a trunk trained canopy will have higher pest severity and incidence than a hanging cane type. The zoospore swims to the nearest stomata in water film, encysts, and germinates with a germ tube and penetrates the leaf. Secondary infection is initiated by sporangia from sporangiophores emerging on the underside of the infected leaf $[4,5]$. Symptoms on the foliage are same in both types of infection. After the zoospore invades the leaf starts the incubation period, which is influenced by environmental factors $[3,8,11,16]$. For example under high humidity the incubation period can be cut half, on the other hand under atmospheric drought sporangiophores do not form [8, 16]. After the incubation period yellowish circular spots develop, these are often mentioned as "oilspots" [1, 4-9, 12], while on the underside of the leaves in the spots sporangiophores with sporangia develop. After the release of sporangia the spot becomes necrotic. In the second half of the growing season symptoms change, the infection is restricted to veinlets, the round spots become tapestry-like [8].

If symptoms in spring occur on the upper side of the canopy the infection is "carried in" the vineyard [2] with wind.

Corresponding author. Tel.: +36 76 517-726

E-mail address: agoston.janos@kvk.uni-neumann.hu 


\section{Method}

Experiments and observations were made in Bács-Kiskun County. Host plant phenology and disease data were retrieved from the Plant Protection Information System (NIR) and from the reports of district plant protection inspectors of the Government Office of Bács-Kiskun County, the observations of Gábor Mezö, Tamas Hegyi and the author.

The reporting of pest severity was carried out by the protocols of EPPO and Agricultural Administrative Agency (MGSZH) [13-15, 17]. Charts were made with Microsoft Office Excel.

\section{Results}

Fruit bunch downy mildew occurrence in mid June in 2009 was $4 \%$, this is low infection severity. By the end of August the overall infection was $14 \%$, and only $1 \%$ was medium severity. (Figure 1.).

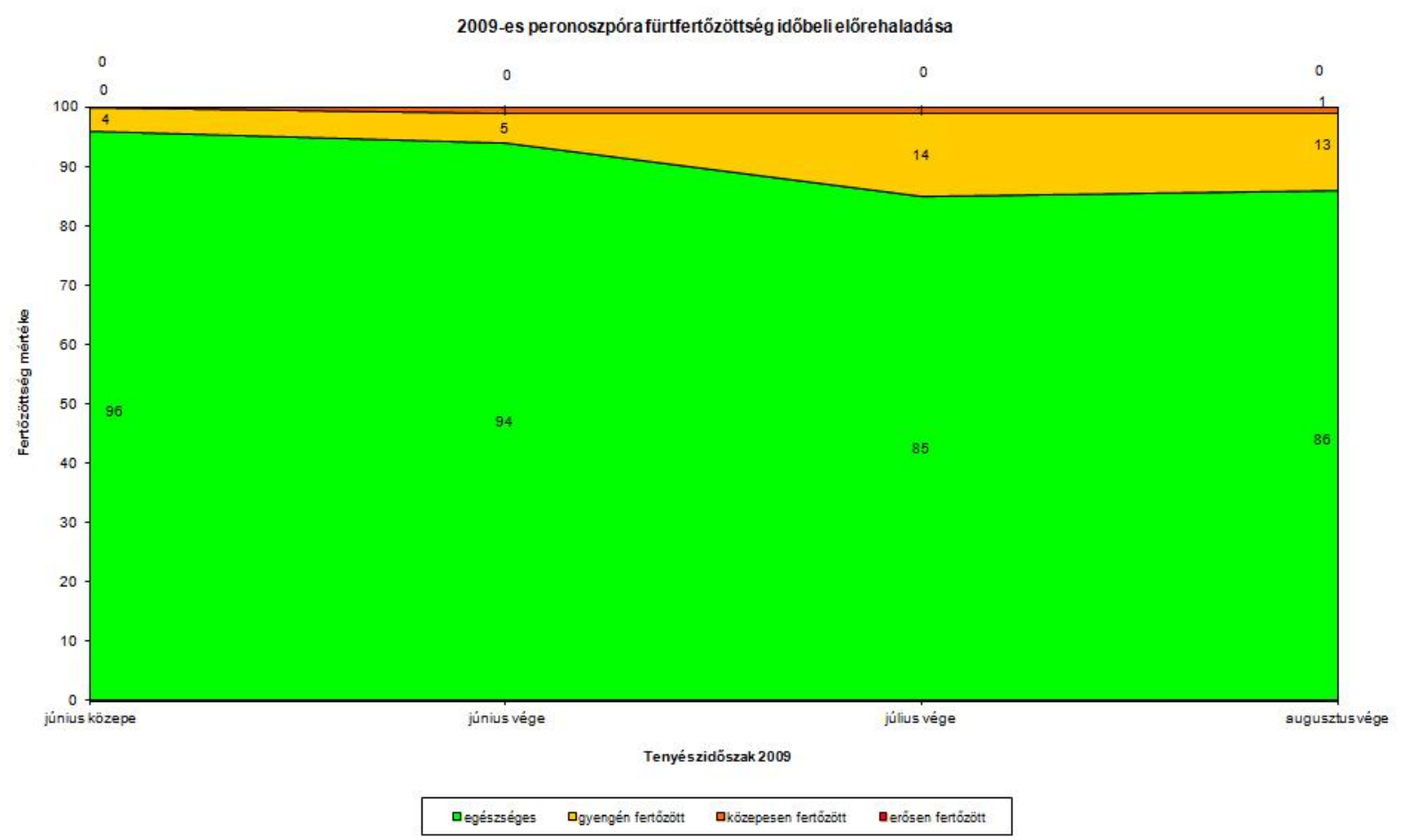

Figure 1. Infection dynamics of grape downy mildew on grape fruit bunch 2009

In contrast the pest occurrence in mid June in 2010 was 74\%. From this 50\% had low, 23\% medium, and $1 \%$ high severity. At the end of August pest occurrence reached $90 \%$, of which $37 \%$ had low, $42 \%$ medium, and $11 \%$ high pest severity (Figure 2 .). 


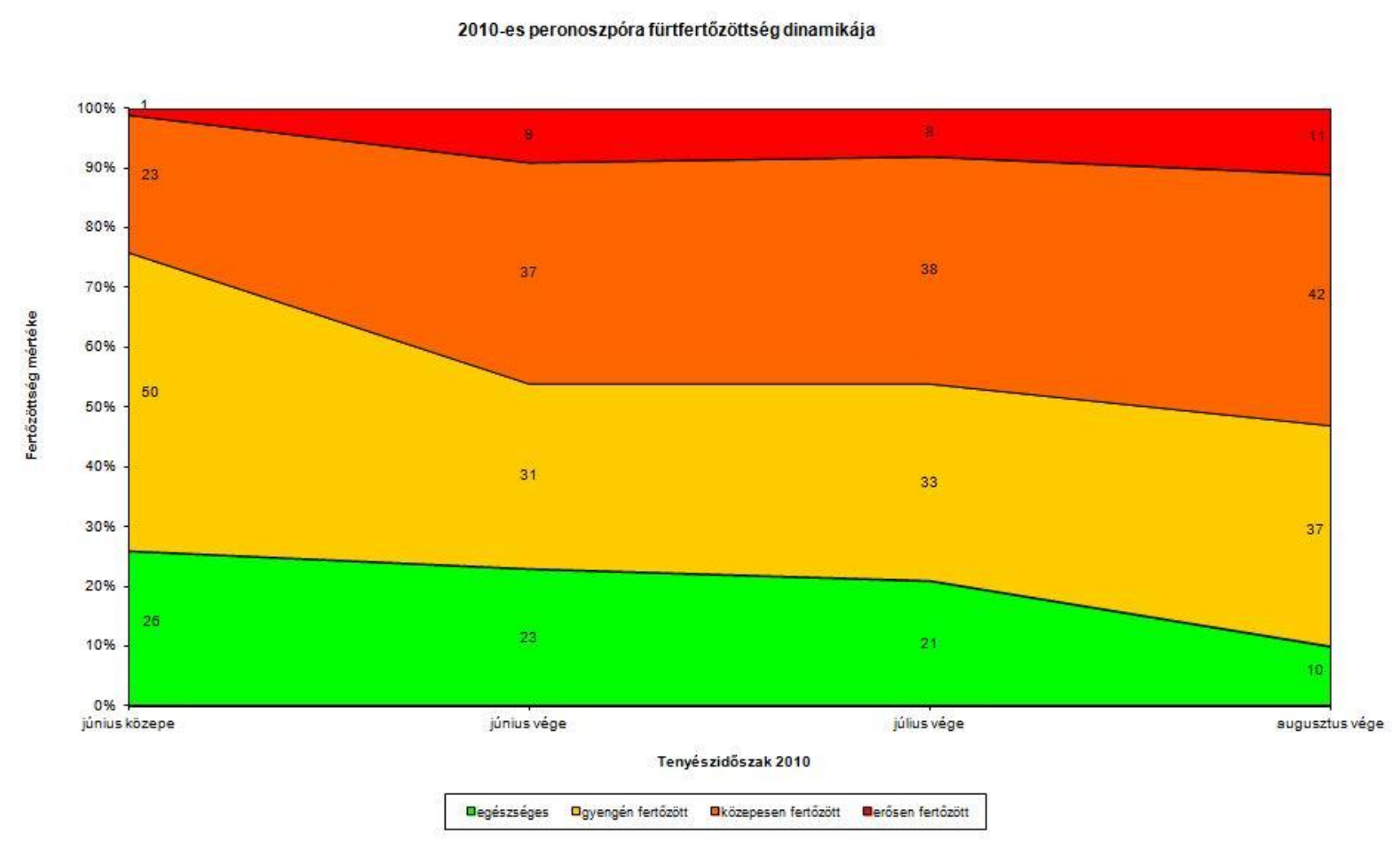

Figure 2. Infection dynamics of grape downy mildew on grape fruit bunch 2010

In the case of grape downy mildew over $25 \%$ of pest occurrence on fruit bunch considered an epidemic. County.

Based on the upper data in 2010 downy mildew reached epidemic levels in Bács-Kiskun

\section{Discussion}

Downy mildew is present in every Hungarian grape vineyard. To avoid epidemic, growers may want to operate an automated downy mildew forecast system. Chemical treatments should be carried out at the forecasted date.

In case of serious defoliation one have to take into account next year the flower count will be lower, which means lower yields. Canes will not reach maturity. In case of a cold winter, frost injury will be more serious. Weakened plants will show stronger ESCA symptoms and become more susceptible to disposition parasites.

Care should be taken at pruning, keeping the balance of fruit bunches and vegetative canopy. Infected parts should be discarded, leaf litter should be dug in the soil, this way one can minimize the inoculums for next year.

\section{Conclusions}

With properly selected fungicides applied at the right time grapes can be kept at low pest severity $(37 \%)$ or disease free $(10 \%)$ even under epidemic conditions.

\section{Acknowledgment}

l'd like to express my gratitude towards Gábor Mező, Tamás Hegyi for their observation, Edit Szücs for NIR and meteorological data, and her help in assessment of the trials and her assistance in the laboratory.

Thank you for the support of the research carried out in the framework of the EFOP-3.6.2-162017-00012 „Developing a functional, healthy and safe food product chain model from field to table 
in a thematic research network". The project is funded by the Hungarian State and the European Union, co-financed by the European Social Fund, and is part of the Széchenyi 2020 program.

\section{References}

[1] Brooks A., Halstead A., Royal Horticultural Society (1999) Garden pests and diseases. Mitchell Beazley, London. ISBN: 978-1-84000-155-6.

[2] Gáspár I., Novák J., Pecze R. (1996) Lehetett-e szállított inokulum az 1995. évi szőlőperonoszpóra-fertőzés oka Bács-Kiskun megyében? Agrofórum 7:55-56.

[3] Gilles T. (2004) Forecasting Downy Mildew Diseases. In: Spencer-Phillips P, Jeger M (eds) Advances in Downy Mildew Research — Volume 2. Springer Netherlands, Dordrecht. pp. 35-67. ISBN: 978-90-481-6697-8. DOI: 10.1007/978-1-4020-2658-4_2

[4] Glits M., Folk Gy. (2007) Kertészeti növénykórtan. Mezőgazda Kiadó, Budapest. ISBN: 978-963-286-297-2.

[5] Glits M., Folk Gy. (1997) Kertészeti növénykórtan. Mezőgazda Kiadó, Budapest. ISBN: 978-963-7362-69-9.

[6] Glits M., Horváth J., Kuroli G., Petróczi I. (eds) (1997) Növényvédelem. Mezőgazda Kiadó, Budapest. ISBN: $978-$ 963-286-042-8.

[7] Hluchý M., Ackermann P., Zacharda M., Laštůvka Z., Bagar M., Jetmarová E., Gáspár V., Szőke L., Plíšek B. (2007) A gyümölcsfák és a szőlő betegségei és kártevői. Biocont Laboratory Ltd. Brno-Slatina, CZ, Brno. ISBN: 978-80-901874-9-8.

[8] Lehoczky J., Reichart G. (1968) A szőlő védelme. Mezőgazdasági Kiadó, Budapest.

[9] Mező G. (1995) Szőlőperonoszpóra járvány Bács-Kiskun megyében 1995-ben. Növényvédelem 31:593-595.

[10] Növény és Talajvédelmi Állomás (1990) NIR: Növényvédelmi Információs Rendszer. Növény és Talajvédelmi Állomás, Budapest.

[11] Park E. W., Seem R. C., Gadoury D. M., Pearson R. C. (1997) DMCast: a prediction model for grape downy mildew development. Viticultural and Enological Science 52:182-189.

[12] Vétek G., Nagy G. (2011) Kártevők és kórokozók a kertben: károsítók azonosítása és a védekezés lehetőségei. Cser Kiadó, Budapest. ISBN: 978-963-278-208-9.

[13] (2004) Általános vizsgálati módszertan. Mezőgazdasági Szakigazgatási Hivatal, Budapest.

[14] (2012) Conduct and reporting of efficacy evaluation trials, including good experimental practice. EPPO Bulletin 42:382-393. DOI: 10.1111/epp.2611

[15] (2004) Fungicid és baktericid vizsgálati módszertan. Mezőgazdasági Szakigazgatási Hivatal, Budapest.

[16] (1994) HP-100 használati utasítás. G. Lufft Mess- und Regeltechnik GmbH.

[17] (2001) Plasmopara viticola. EPPO Bulletin 31:313-317. DOI: 10.1111/j.1365-2338.2001.tb01000.x 